\title{
Research Progress of Biodegradable Polyester Polyols Based on Ring-Opening Polymerization of Cyclohexene Carbonate
}

\author{
Xuemei WANG ${ }^{1}$, Xiang GUI ${ }^{1}$, Yingping $\mathrm{QI}^{2}$, Yongfeng $\mathrm{SHEN}^{2}$, Hua $\mathrm{LI}^{1}{ }^{*}$ \\ ${ }^{1}$ School of Chemical and Energy Engineering, Zhengzhou University, No. 100 Science Road, Zhengzhou, Henan, China \\ ${ }^{2}$ Zhengzhou Museum, No. 168 Songshan South Road, Zhengzhou, Henan, China \\ crossref http://dx.doi.org/10.5755/j01.ms.26.3.21964
}

Received 30 October 2018; accepted 16 January 2019

\begin{abstract}
The polycarbonate polyols( $\mathrm{PCD}$ ) obtained by ring-opening polymerization of a general cyclic monomer is mostly a linear flexible structure, which is used as a raw material to synthesize polyurethanes, and it is difficult to simultaneously ensure good thermal-mechanical properties and weather resistance due to insufficient rigidity of the main chain. However, PCD based on ring-opening polymerization of cyclohexene carbonate $(\mathrm{CHC})$, endowing with polyurethanes good mechanical properties, weather ability and biological stability because of the rigid structure of six-membered aliphatic rings in the main chain. Therefore, in this paper, the method and principle of preparing new polycarbonate polyols based on ringopening polymerization of cyclohexene carbonate $(\mathrm{CHC})$ are introduced. And the problems and countermeasures in its development and its application in polyurethane materials are discussed.

Keywords: cyclic carbonate, polycarbonate polyol, ring-opening polymerization, biodegradable polymers.
\end{abstract}

\section{INTRODUCTION}

Polycarbonate polyol refers to a hydroxyl-terminated polymer containing a repeating unit of a carbonate group in the main chain of the molecule [1,2], which is one of important raw materials for synthesizing polyurethane, which accounts for $60-80 \%$ of polyester polyurethane, which is already in use as intermediates in the manufacture of polyurethanes for high-performance coating applications [3-8]. Polycarbonate polyols have been extensively used to manufacture biocompatible biomaterials, showing high mechanical properties [9], which represent a very fast developing market in the field of specialty elastomers used in medical applications due to their very good mechanical properties, biocompatibility and low toxicity [10]. Compared with polyesters and polyethers, polyurethanes synthesized with polycarbonate polyols have better hydrolysis resistance, good elastomeric properties, higher mechanical properties, improved resistance at low temperature, improved ageing and oil resistance [12-18]. Futhermore, the new type of polycarbonate diols, which are liquid at room temperature, are easy for handling, and improved in flexibility and chemical resistance when prepared polyurethane, compared with conventional (solid at laboratory conditions) polycarbonate diols [19, 20]. Therefore, the research and development of polycarbonate polyols and related polyurethane materials have received extensive attention.

As the main polyurethane material, polycarbonate polyols, as compared traditional polyester polyurethane, impart better hydrolysis resistance, improved mechanical properties, and increase heat resistance and oxidation resistance of the polyurethanes [21-23]. However, there have been few studies dealing with the synthesis and characterisation of polyurethanes based on polycarbonate diols [3, 13, 17, 24-33].

In the past few decades, there have many studies related to polycarbonate polyols derived from the copolymerization of carbon dioxide $\left(\mathrm{CO}_{2}\right)$ and epoxides [34-45], while only a few publications have been devoted to polycarbonate polyols synthesized by ring-opening polymerization of cyclic monomers [46-53]. To our knowledge, only several publications have dealt with polycarbonate diol based on cyclohexene carbonate (CHC) [54-57]. $\mathrm{CHC}$ is a aliphatic polymers with six-membered alicyclic rigid chain structure in the main chain, which have a wide range of potential applications and can be designed to biodegrade when placed in the appropriate environment, eventually to carbon dioxide and neutral glycol [58-61]. In this sense, synthetic biodegradable aliphatic polycarbonate polyols based on ring-opening polymerization of cyclohexene carbonate have a great advantage, since recent advances in polymer science and technology have made it possible to design and synthesize at a great variety of polymers with desirable properties, which are a good substitute for petroleum polyols in industry, meeting the requirements of green chemistry and sustainable development.

\section{PREPARATION AND REACTION PRINCIPLE OF POLYCARBONATE POLYOLS}

Aliphatic polycarbonate polyols are mainly prepared by poly-condensation between diols and carbonate or between diols and chloroformate [62], copolymerization of epoxides and $\mathrm{CO}_{2}$ in the presence of organic metal catalysts [63], and ring-opening polymerization of cyclic carbonates [54-55]. Among them, ring-opening polymerization of cyclic

\footnotetext{
* Corresponding author. Tel.: 0086-371-67781801; fax: 0086-371-

63886154. E-mail address: lihua@zzu.edu.cn (H. Li)
} 
carbonates is considered to be one of the more effective synthetic techniques on account of the high levels of control that is possible over the molecular parameters of the resulting polymers [64]. The ring-opening polymerization of cyclic polycarbonate can be divided into cationic polymerization, anionic polymerization, coordinated polymerization, enzymatic ring-opening polymerization and nucleophilic polymerization according to the different catalyst/primer systems used in the ring-opening polymerization of monomers.

\subsection{Cationic ring-opening polymerization of cyclic carbonate}

Main characteristics of ring-opening polymerization of cation catalyzed cyclocarbonate is that the polymerization intermediate is an exocyclic carbonyl oxygen which is electrophilically attacked to form a carbonyl carbocation intermediate. Monomers generally break open through alkoxic bond, and the side reaction of $\mathrm{CO}_{2}$ removal is often accompanied by carbon cation rearrangement, forming polyether chain node units in the polymer [65]. Catalytic systems for cationic ring-opening polymerization are mainly divided into three categories: protonic acids, stable carbon cations or covalent compounds that can produce carbon cations, and Lewis acids. Such as $\mathrm{FSO}_{3} \mathrm{CH}_{3}, \mathrm{FSO}_{3} \mathrm{H}$, $\mathrm{CF}_{3} \mathrm{SO}_{3} \mathrm{Me}, \mathrm{CF}_{3} \mathrm{SO}_{3} \mathrm{H}, \mathrm{FSO}_{3} \mathrm{CH}_{2} \mathrm{CH}_{3}, \mathrm{p}-\mathrm{NO}_{2} \mathrm{C}_{6} \mathrm{H}_{4} \mathrm{SO}_{3} \mathrm{CH}_{3}$, $\mathrm{BF}_{3} \cdot \mathrm{OEt}_{2}$, etc. [55, 66].

Kricheldorf et al. first study the mechanism of cationic ring-opening polymerization of six-membered cyclic carbonates [67]. $\mathrm{CH}_{3} \mathrm{OSO}_{2} \mathrm{CF}_{3}$ is used as catalyst to alkylate the extracyclic oxygen atoms of the monomers to form two active centers, which are in equilibrium in the reaction system. Then, another monomer molecule nucleophilically attacks the active centers, resulting in the breakage of alkoxy bonds, while the monomer molecule as a nucleophile is alkylated (Fig. 1). Removal of $\mathrm{CO}_{2}$ is the main side reaction in ring-opening polymerization of cyclic carbonate catalyzed by $\mathrm{CF}_{3} \mathrm{SO}_{3} \mathrm{R}\left(\mathrm{R}=\mathrm{H}, \mathrm{CH}_{3}\right)$, which results in the presence of ether bonds in the polymer. The transfer of intramolecular alkyl groups is the main reason for the formation of ether linkages. According to different of cyclic carbonate, cationic catalyst and reaction temperature, the polymer generally contains $5 \%-10 \%$ ether bond.<smiles>CC1OC(=O)C(C)OC1=O</smiles>

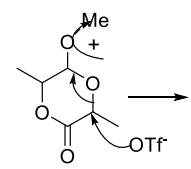

$$
\text { Me- } \prod_{0}^{-O}
$$

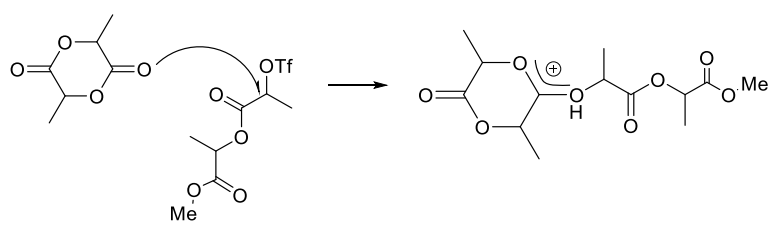

Fig. 1. Schematic diagram of cationic polymerization mechanism [67]

Kazuhisa Terao et al. synthesize PTMC with two terminal hydroxyl groups by ring-opening polymerization of trimethylene cyclocarbonate (TMC), using DBU (1, 8diazodicyclic undecano-7-ene) as the catalyst and polyethylene glycol as the initiator [68]. Abdou Khadri Diallo et al. synthesize the random copolymer P (CHC-coTMC) of cyclohexene carbonate CHC and TMC by using organic catalyst TBD [55]. The 1H NMR of the product shows no signal of the ether bond, indicating that the decarboxylation reaction does not occur during the polymerization.

\subsection{Anionic ring-opening polymerization of cyclic carbonate}

Compared with cationic ring-opening polymerization, anionic ring-opening polymerization can obtain higher molecular weight polymers [69]. The anion-catalyzed cyclic carbonate polymerization is mainly due to the fact that the alkane carbon directly connected to oxygen is attacked by anions, which is also open-loop due to the cleavage of alkoxy bonds [70]. However, there is no rearrangement of anions and removal reaction of $\mathrm{CO}_{2}$, so there is no polyether segment in the polymer. However, the anionic active center has strong reactivity, which can attack carbonyl groups on the polymer chain, leading to interesterification and formation of low-molecular weight cyclic oligomers, which are soluble in the precipitation agents such as methanol, thus resulting in low polymerization conversion [71].

The initiator of anionic open-loop polymerization is mainly the alkyl compound or alkoxyl compound of alkali metals or alkali earth metals, such as s-BuLi [58], Bu2Mg [72] and $\mathrm{t}-\mathrm{BuOK}$ [73]. The mechanism of Anionic ring-opening polymerization of cyclic carbonate [74] is that anions attack the six-membered cyclic carbonate monomer during the chain initiation process, and protonation of the monomer results in the formation of anion in active center, which attacks the cyclic monomer and promotes the chain growth (Fig. 2).

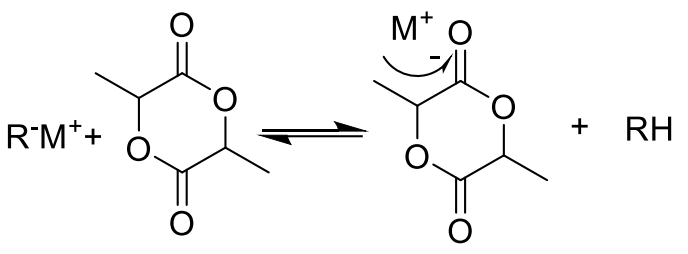<smiles>[R16]OC(C)C(=O)OC(C)C([R])=O</smiles>

$\mathrm{R}=$ alkyl,alkoxy and $\mathrm{M}=\mathrm{Li}, \mathrm{K}, \mathrm{Mg}$

Fig. 2. Schematic diagram of anionic polymerization mechanism [74]

Zhang $X$ et al. [75] reported an effective catalytic system combining alkoxides with thioureas that the thioimidate anion simultaneously activates the alcohol initiator/chain-end and the lactone monomer to effect the selective ring-opening of lactones and carbonates. As shown in Fig. 3, thioimidates were generated in situ by deprotonation of neutral thiourea TU-1 with sodium, potassium or imidazolium alkoxides. 


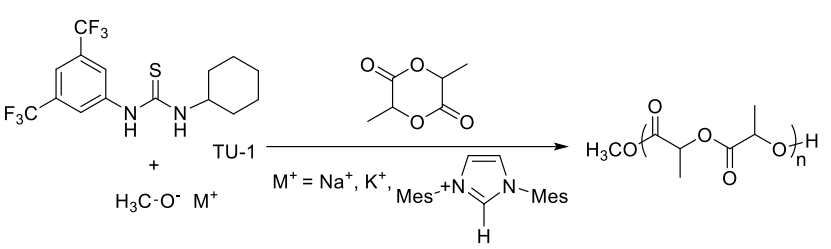

Fig. 3. Ring-opening polymerization of L-lactide catalysed by anionic thioimidates [75]

\subsection{Coordinated ring-opening polymerization of cyclic carbonate}

The initiators of coordination polymerization are mainly metal compounds with empty $\mathrm{p}, \mathrm{d}, \mathrm{f}$ orbitals and greater electronegativity, including $\mathrm{S} \mathrm{n}, \mathrm{Ti}, \mathrm{Zn}, \mathrm{Z}$ r, M n, Sb and rare earth elements [76]. The advantage of this catalyst is that it can be used to prepare polymers with high conversion and high molecular weight, and the reaction conditions are easily controlled. Fig. 4 [77] illustrates a typical coordination-insertion mechanism [78] for the case of ROP of lactide that includes three steps: a. coordination of the monomer carbonyl onto the metal ion giving electrophilic activation of the carbonyl carbon; b. nucleophilic addition of the alkoxide to the carbonyl group to give a bicyclic complex; and c. ring opening by acyloxygen bond cleavage.

"Coordination-insertion" ROP mechanism

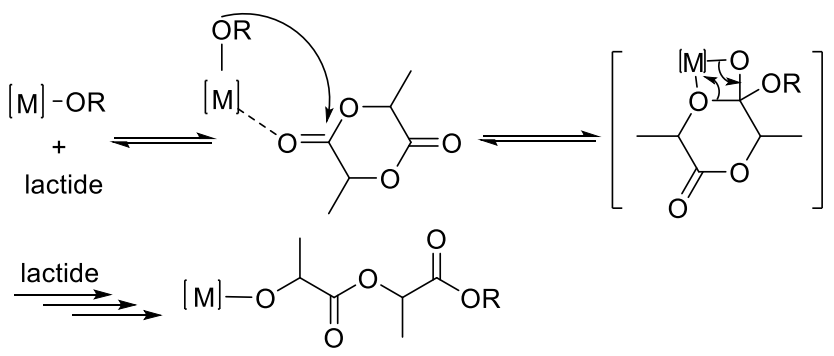

Fig. 4. Coordination-insertion mechanisms in ROP of lactide [77]

The ring-opening polymerization (ROP) of racemic trans-cyclohexene carbonate (rac-CHC) and enantiopure trans-(R, R)-CHC is successfully obtained by William et al. [54]. Poly(cyclohexene carbonate) (PCHC) (Fig. 5) is obtained by ROP of rac-CHC catalyzed by zinc diaminophenolate, zinc $\beta$-diketiminate, yttrium bis(phenolate), or 1,5,7-triazabicyclo[4.4.0]dec-5-ene (TBD) in combination with an alcohol as a coinitiator. $\mathrm{H}$

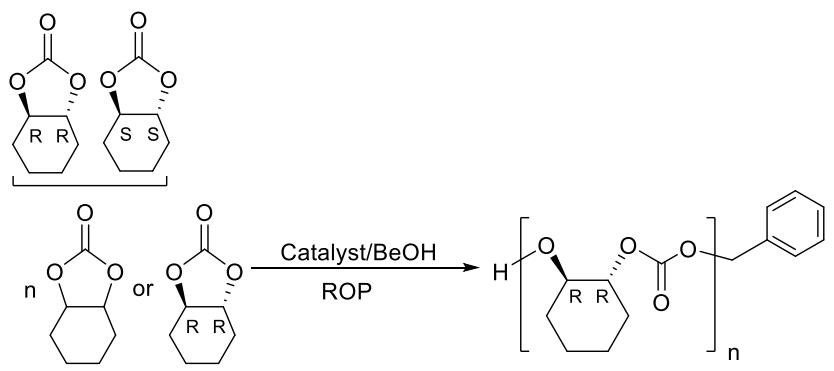

Fig. 5. ROP of CHC by Metallic or Organic Catalysts [54]

And the reaction proceeds without decarboxylation, affording PCHC with the molecular weight up to $17000 \mathrm{~g} / \mathrm{mol}$ and $\mathrm{ĐM}=\mathrm{ca} .1 .2$, realizing the first synthesis of a purely isotactic PCHC, which is a semicrystalline polycarbonate featuring a high $T_{\mathrm{g}}$ of $130{ }^{\circ} \mathrm{C}$.

Abdou Khadri Diallo et al. [79] synthesized Block and random copolymers of racemic- or enantiopure trans-(R,R)cyclohexene carbonate, upon sequential and random copolymerization of racemic-trans-cyclohexene carbonate (rac-CHC) or enantiopure trans-(R,R)-cyclohexene carbonate ((R,R)-CHC) with L-lactide (LLA) or trimethylene carbonate (TMC), using active [(NNO)ZnEt] or $\mathrm{Y}\left[\mathrm{N}\left(\mathrm{SiMe}_{3}\right)_{2}\right]_{3}$ complexes or TBD organocatalyst, combined to an alcohol (BnOH or iPrOH) as a initiator/chain-transfer agent. As shown in Fig. 6, three different polymers were finally obtained, respectively.

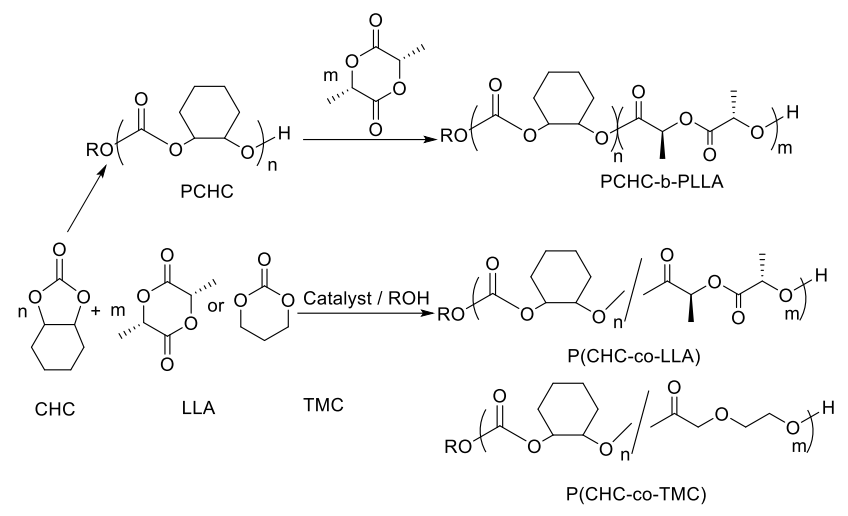

Fig. 6. Synthesis of copolymers by ring-opening copolymerization of CHC with LLA or TMC [79]

\subsection{Enzymatic ring-opening polymerization of cyclic carbonate}

The enzyme not only catalyzes the degradation of cyclic carbonates [80], but also catalyzes its ring-opening polymerization [81-83]. Enzymatic ring-opening polymerization has many advantages. Enzymes are chemoselective, regioselective, stereoselective and enantioselective [84-86]. The first enzymatic preparation of block poly (ester-co-carbonate) was completed by Dai $\mathrm{S}$ and co-workers [87], and enzymatic ring-opening polymerization of TMC with PHB-diol obtained di-block poly (HB-co-TMC)s (Fig. 7) with controlled weight percentage of the blocks and controlled molecular weight, using telechelic hydroxylated poly[(R)-3-hydroxybutyrate] [PHB-diol; $\mathrm{Mn}=3000 \mathrm{~g} / \mathrm{mol}$ (GPC)] as initiator.

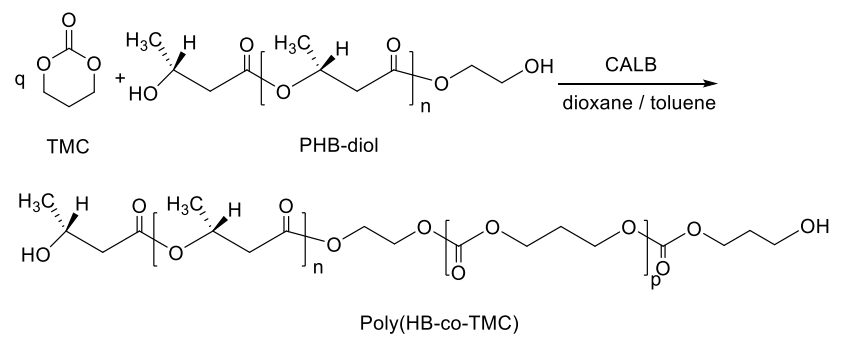

Fig. 7. Novozym 435-catalyzed ROP of trimethylene carbonate (TMC) [87]

Marcin Sobczak [88] studied the enzyme-catalyzed ring-opening Polymerization of cyclicesters in the presence of poly (ethylene glycol). In this study, low-molecularweight polyesters, terminated at both sides by hydroxyl groups, were obtained by the ring-opening 
copolymerization of cyclic esters (Fig. 8) in the presence of PEG/lipase systems.

$$
\text { }
$$

Fig. 8. N-435-catalyzed (co)polymerization of LA with GL initiated by PEG [88]

Enzyme-catalyzed reactions like this generally follow such a mechanism [89-91]: cyclic carbonate is opened by a lipase to obtain an acyl-enzyme intermediate, which is then reacted with the $\mathrm{OH}$ group of an initiator to produce a carbonate containing a terminal hydroxyl group; further reaction of this molecule with the acyl-enzyme intermediate leads to elongation of the chain.

\subsection{Nucleophilic ring-opening polymerization of cyclic carbonate}

In many literatures $[77,92,93]$, the nucleophilic polymerization mechanism is also called the monomer activation mechanism, and the typical catalyst is $\mathrm{HCl} \cdot \mathrm{Et}_{2} \mathrm{O}$ solution. HOON HYUN et al. use polyethylene glycol PEG1000 as initiator and $\mathrm{HCl} \cdot \mathrm{Et}_{2} \mathrm{O}$ solution as catalyst to synthesize a diblock copolymer of polyethylene glycol and polytrimethylene carbonate by monomer activation mechanism [94]. It is found that the hydroxyl-terminated polyethylene glycol initiator could not initiate the ringopening polymerization of TMC alone, but in the presence of $\mathrm{HCl} \cdot \mathrm{Et}_{2} \mathrm{O}$, the polymerization of $\mathrm{TMC}$ can be catalyzed by the monomer activation mechanism to obtain the PEGPTMC block copolymer, which shows that the interaction between $\mathrm{H}+$ as a nucleophilic reagent and carbonyl oxygen activates the monomer(Fig. 9), which greatly improves the nucleophilic attack of alcohol oxygen on carbonyl carbon, thus realizing the ring-opening of cyclic carbonate.

The block copolymers of PPG and PCL have good mechanical properties that their respective homopolymers do not have. Therefore, block copolymers of PPG and CL are synthesized by ring-opening copolymerization of $\mathrm{CL}$ using PPG as initiator and $\mathrm{HCl} \cdot \mathrm{Et}_{2} \mathrm{O}$ as monomer activator [95]. It has been found that the conversion of the monomer and the molar mass of the polymer increase linearly with the increase of polymerization time. After $24 \mathrm{~h}$, the conversion rate of CL was almost unchanged. The theoretical value of Mn obtained by NMR analysis is close to that calculated by the conversion rate of monomer CL, while the dispersion index PDI of PCL-PPG-PCL triblock copolymer increases slightly with the increase of reaction time, and the PDI reaches 1.18 after 24 hours, which indicates that even if the monomer is completely transformed, the reaction system still has certain activity and the reaction does not terminate.

Matsuo et al. use the alcohol-acid system nBuOHPCF 3 COOH (TFA) and $\mathrm{PhCH}_{2} \mathrm{OHPTFA}_{3}$ to catalyze the polymerization of TMC in toluene at $50{ }^{\circ} \mathrm{C}$ for $4 \mathrm{~h}$ to obtain a polymer with $\mathrm{Mn}=2500-6800$, which do not contain ether bonds, indicating that no side effects of $\mathrm{CO}_{2}$ are removed [96].
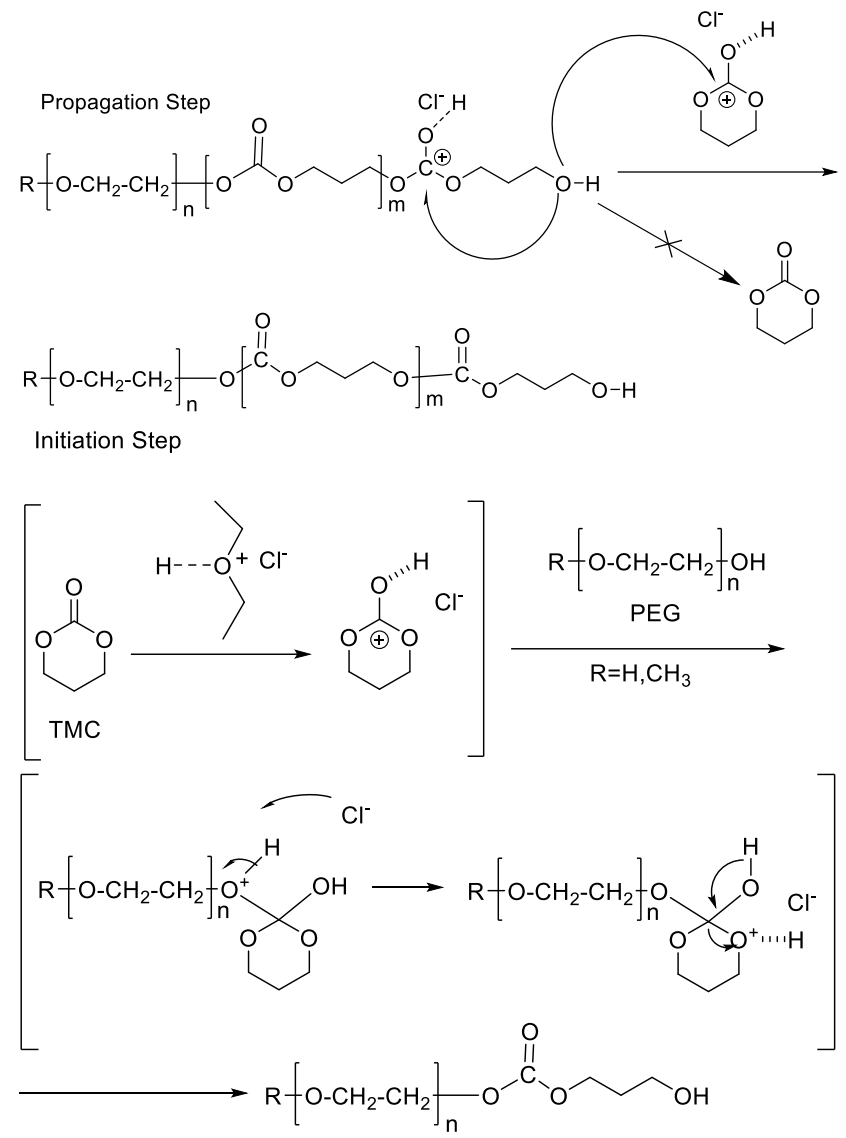

Fig. 9. Schematic diagram of monomer activation mechanism

However, under the same reaction conditions, TMC is initiated only by alcohols, but no polymerization occurs, which indicates that proton $\mathrm{H}+$ is activating agent for ringopening polymerization of monomers, attacking carbonyl carbon of TMC, thus breaking open the acyl oxygen bonds of TMC and forming adducts containing hydroxypropyl terminal group; then, the oxygen on the hydroxypropyl terminal group nucleophilically attacks Carbonyl carbon of TMC to carry out chain growth.

\section{APPLICATION OF POLYCARBONATE POLYOLS IN POLYURETHANE MATERIALS}

Polyols and isocyanates are the raw materials of polyurethane, and proper selection of polyols can produce polyurethane with various properties. The polyurethane produced with polycarbonate polyol is better in heat resistance [21, 22] and hydrolysis resistance [23] than that produced with caprolactone diol. Polycarbonate polyurethane has excellent oxidation resistance in vivo, which is widely used in the field of aqueous environment and long-term implanted medical devices [10]. At the same time, polycarbonate polyols also have microbial degradability, which makes them become a kind of environmentally friendly materials $[59,61]$.

As early as the early 1970s, Muller et al. prepared polyurethane elastomers by using a mass fraction of $10-50 \%$ polycarbonate, 1, 6-hexanediol (PHMCD) and a polyester mixture of $50-90 \%$ as soft segments, adding appropriate chain extenders containing reactive hydrogen to 
react with isocyanate [97]. PHMCD is synthesized from 1, 6-diethylene glycol and diphenyl carbonate. Compared with polyether or polyester polyurethane elastomers, these polyurethane elastomers have more excellent physical and mechanical properties and hot water resistance.

Schappacher et al. [98] study the copolymerization of $\varepsilon$ caprolactone (CL) monomer with TMC monomer, and the degradability of the copolymer product is increase to some extent. Shohei et al. [99] find that polycarbonate polyurethane binder can significantly improve the battery capacity and battery durability when used in the preparation of electrodes. In addition, due to the good biocompatibility and low toxicity and permeability of the polymer products, a polymer product which is both soft and strong in strength can be obtained, so as to be used in the preparation of nerve catheters [100].

Polycarbonate polyurethanes are also widely used in other industries. In the construction industry, polycarbonate sheet has obvious technical advantages over inorganic glass used traditionally in the construction industry because of its good light transmittance, shock resistance, ultraviolet radiation resistance and dimensional stability of its products and good contour machining performance[3, 6, 8]; In the packaging industry, PC bottles have completely replaced glass bottles in some fields because of the advantages of light weight, good shock resistance and good transparency of polycarbonate products, non-deformation and transparency when treated with hot water and corrosive solutions $[12,33]$; In the electronic industry, polycarbonate is an excellent insulating material because of its good and constant electrical insulation in a wide range of temperature and humidity [30]. At the same time, its good flammability and dimensional stability make it a broad application field in the electronic and electrical industry $[14,15]$.

\section{PROBLEMS AND DEVELOPMENT COUNTERMEASURES IN THE SYNTHESIS OF POLYCARBONATE POLYOLS}

Conventional aliphatic polycarbonate polyols are mostly synthesized using homopolymers of monomers such as ethylene carbonate (EC), propylene carbonate (PC), trimethylene carbonate (TMC), or copolymers of the two. The main chain is mostly a linear flexible structure, which is used as a raw material to synthesize polyurethane, and it is difficult to simultaneously ensure good thermalmechanical properties and weather resistance due to insufficient rigidity of the main chain [9]. Whereas, the cyclohexene carbonate (CHC) is a five-membered cyclic carbonate containing a six-membered alicyclic rigid structure [54]. If a suitable catalyst/initiator system is used for ring-opening polymerization or copolymerization with other cyclic monomers, the degradation rate of $\mathrm{CHC}$ is significantly higher than that of PTMC and PEC [79]. In addition, due to the good biocompatibility of the polymerization products and low toxicity and permeability, a polymer product which is both soft and strong in strength can be obtained by reasonably adjusting the ratio of the two components in the copolymer, thus ensuring machinability and weatherability of polycarbonate polyurethane [10].

In addition, five-membered cyclic carbonate is the smallest volume, but also relatively stable cyclic carbonate, which is difficult to carry out ring-opening polymerization [101]. Therefore, it is of great significance for the development of novel biodegradable polycarbonate polyols to explore the catalytic/initiator systems and polymerization conditions for ring-opening polymerization of pentacyclic carbonate with high performance. Among the many catalysts for ring-opening polymerization, polycarbonate catalyzed by coordination metal catalysts such as Al, Sn and rare earth elements has the characteristics of high molecular weight, narrow molecular weight distribution and less side reactions, so it is the focus of future research.

\section{CONCLUSIONS}

Open-ring polymerization of cyclic carbonates is an effective technology for the synthesis of polycarbonate polyols. In this paper, five typical mechanisms of ringopening polymerization of cyclic polycarbonate are introduced based on different catalyst/initiator systems used in monomer ring-opening polymerization. An important application of polycarbonate polyols is the synthesis of aliphatic polycarbonate-based polyurethane materials. The aliphatic polycarbonate polyurethane degrades to produce non-toxic $\mathrm{CO}_{2}$ and neutral glycol, which is a biodegradable material with good machinability and biocompatibility, which are copolymerized with other cyclic monomers such as ethylene carbonate, propylene carbonate, and caprolactone by changing the chemical structure of the main chain and introducing side chain functional groups. Or after being blended with other biodegradable materials, the polymer can have better physical, chemical and biological properties, which will have broader application prospects in the fields of biomedical fields, food packaging, adhesives and other fields.

\section{REFERENCES}

1. Tanaka, H, Kunimura, M. Mechanical Properties of Thermoplastic Polyurethanes Containing Aliphatic Polycarbonate Soft Segments with Different Chemical Structures Polymer Engineering \& Science 42 (6) 2002: pp. $1333-1349$.

https://doi.org/10.1002/pen.11035

2. Foy, E., Farrell, J.B., Higginbotham, C.L. Synthesis of Linear Aliphatic Polycarbonate Macroglycols Using Dimethylcarbonate Journal of Applied Polymer Science 111 (1) 2010: pp. 217-227. https://doi.org/10.1002/app.28887

3. Eceiza, A., Larrañaga, M., Caba, K.D.L., Kortaberria, G., Marieta, C., Corcuera, M.A., Mondragon, I. Structureproperty Relationships of Thermoplastic Polyurethane Elastomers Based on Polycarbonate Diols Journal of Applied Polymer Science 108 (5) 2010: pp. 3092 -3103. https://doi.org/10.1002/app.26553

4. Kuta, A., Hrdlička, Z., Strachota, A., Spirkova, M. The Influence of Macrodiol Type on the Mechanical Properties of Polyurethane Materials Advanced Manufacturing Processes 24 (10) 2009: pp. $1214-1216$. https://doi.org/10.1080/10426910902979553

5. Eceiza, A., Martin, M.D., Caba, K.D.L., Kortaberria, G., Gabilondo, M.A., Corcuera, M.A., Mondragon, I. Thermoplastic Polyurethane Elastomers Based on Polycarbonate Diols with Different Soft Segment Molecular Weight and Chemical Structure: Mechanical and Thermal 
Properties Polymer Engineering \& Science

$48(2)$

2008: pp. $297-306$.

https://doi.org/10.1002/pen.20905

6. Henze, O.S. Flame-retardant Thermoplastic Polyurethane Based on Polycarbonate Diols U.S. Patent No.20150284537.

7. Cakić, S.M., Špírková, M., Ristić, I.S., B-Simendic, J.K., M-Cincovic, M., Poreba, R. The Waterborne Polyurethane Dispersions Based on Polycarbonate Diol: Effect of Ionic Content Materials Chemistry \& Physics $138(1)$ 2013: pp. $277-285$.

https://doi.org/10.1016/j.matchemphys.2012.11.057

8. García-pacios, V., Jofre-Reche, J.A., Costa, V., Colera, M., Martin-Martinez, J.M. Coatings Prepared from Waterborne Polyurethane Dispersions Obtained with Polycarbonates of 1, 6-Hexanediol of Different Molecular Weights Progress in Organic Coatings $76(10)$ 2013: pp. 1484-1493. https://doi.org/10.1016/j.porgcoat.2013.06.005

9. Garcia-Pacios, V., Costa, V., Colera, M., MartinMartinez, J.M. Affect of Polydispersity on the Properties of Waterborne Polyurethane Dispersions Based on Polycarbonate Polyol International Journal of Adhesion \& Adhesives 30 (6) 2010: pp. 456-465. https://doi.org/10.1016/j.ijadhadh.2010.03.006

10. Okada, M. Chemical Syntheses of Biodegradable Polymers Progress in Polymer Science 27 (1) 2002: pp. 87-133. https://doi.org/10.1016/S0079-6700(01)00039-9

11. Khan, I., Smith, N., Jones, E., Finch, D.S., Cameron, R.E. Analysis and Evaluation of a Biomedical Polycarbonate Urethane Tested in an in Vitro Study and an Ovine Arthroplasty Model. Part II: in Vivo Investigation Biomaterials 26 (6) 2005: pp. 633-643.

https://doi.org/10.1016/j.biomaterials.2004.02.064

12. Lee, D.K., Tsai, H.B., Tsai, R.S., Chen, P.H. Preparation and Properties of Transparent Thermoplastic Segmented Polyurethanes Derived from Different Polyols Polymer Engineering \& Science 47 (5) 2007: pp. 695-701. https://doi.org/10.1002/pen.20742

13. Lee, D.K., Tsai, H.B., Wang, H.H., Tsai, R.S. Aqueous Polyurethane Dispersions Derived from Polycarbonatediols Journal of Applied Polymer Science 94 (4) 2004: pp. $1723-1729$.

https://doi.org/10.1002/app.21090

14. Garcia-Pocias, V., Colera, M., Lwata, Y., MartinMartinez, J.M. Incidence of the Polyol Nature in Waterborne Polyurethane Dispersions on Their Performance as Coatings on Stainless Steel Progress in Organic Coatings $76(12)$ 2013: pp. $1726-1729$.

https://doi.org/10.1016/j.porgcoat.2013.05.007

15. Serkis, M., Poręba, R., Hodan, J., Kredatusova, J., Spirkova, M. Preparation and Characterization of Thermoplastic Water-borne Polycarbonate-based Polyurethane Dispersions and Cast Films Journal of Applied Polymer Science 132 (42) 2015: pp. 1-14. https://doi.org/10.1002/app.42672

16. Jofre-Reche, J.A., García-Pacios, V., Costa, V., Víctor Colera, M., Martin-Martinez, J.M. Role of the Interactions Between Carbonate Groups on the Phase Separation and Properties of Waterborne Polyurethane Dispersions Prepared with Copolymers of Polycarbonate Diol Progress in Organic Coatings 88 (11) 2015: pp. 199-211. https://doi.org/10.1016/j.porgcoat.2015.06.029

17. Liu, N., Zhao, Y.H., Kang, M.Q., Wang, J.W., Wang, X.K., Feng, Y.L., Yin, N., Li, Q.F. The Effects of the Molecular Weight and Structure of Polycarbonatediols on the Properties of Waterborne Polyurethanes Progress in Organic Coatings
82 (5) 2015: pp. $46-56$

https://doi.org/10.1016/j.porgcoat.2015.01.015

18. Spirkova, M., Poreba, R., Pavlicevic, J., Kobera, L., Baldrian, J., Pekarek, M. Aliphatic Polycarbonate-Based Polyurethane Elastomers and Nanocomposites. I. The Influence of Hard-segment Content and Macrodiolconstitution on Bottom-up Self-assembly Journal of Applied Polymer Science 126 (3) 2012: pp. 1016-1030.

https://doi.org/10.1002/app.36993

19. Tetsushi, K., Chen, Y.Z., Tetsuo, M. Application of Aliphatic Polycarbonatediol for Polyurethane Coating Kotingu Jiho 220 (1) 2005: pp. 1-5.

20. Pavliević, J., Spirkova, M., Strachota, A., Szecsenyi, K.M. The Influence of Montmorillonite and Bentonite Addition on Thermal Properties of Polyurethanes Based on Aliphatic Polycarbonate Diols Thermochimica Acta 509 (1) 2010: pp. $73-80$. https://doi.org/10.1016/j.tca.2010.06.005

21. Pavličević, J., Špírková, M., Bera, O., Jovičić, M., Pilic, B., Balos, S., Budinski-Simendic, J. The Influence of $\mathrm{ZnO}$ Nanoparticles on Thermal and Mechanical Behavior of Polycarbonate-Based Polyurethane Composites Composites Part B: Engineering 60 (5) 2014: pp. 673-679. https://doi.org/10.1016/j.compositesb.2014.01.016

22. Poreba, R., Spirkova, M., Hrdlicka, Z. Mechanical and Thermomechanical Properties of Polycarbonate-based Polyurethane-silica Nanocomposites Processing and Application of Ceramics 5 (3) 2011: pp. 155-159. https://doi.org/10.2298/PAC1103155P

23. Nefzger, H., Barnes, J.M., $\quad$ Schmidt, M., Krause, J. Polyurethane and Polyurethane Urea Elastomers Based on Polycarbonate Polyols: US8273846 B2 2012.

24. Zhou, Y., Wu, G.L., Zhuo, R.X., Liu, Z.L. Synthesis and Properties of Novel Aliphatic Poly(Carbonate-Ester)s European Polymer Journal 45 (7) 2009: pp. 1868-1872. https://doi.org/10.1016/j.eurpolymj.2009.04.022

25. Eceiza, A., Martin, M.D., Caba, K.D.I., Kortaberria, G., Gabilondo, N. Corcuera, M.A., Mondragon, I. Thermoplastic Polyurethane Elastomers Based on Polycarbonate Diols with Different Soft Segment Molecular Weight and Chemical Structure: Mechanical and Thermal Properties Polymer Engineering \& Science $48(2)$ 2008: pp. 297-306. https://doi.org/10.1002/pen.20905

26. D'Arlas, B.F., Rueda, L., Koro, D.L.C., Mondragon, I., Eceiza, A. Microdomain Composition and Properties Differences of Biodegradable Polyurethanes Based on MDI and HDI Polymer Engineering \& Science 48 (3) 2008: pp. $519-529$. https://doi.org/10.1002/pen.20983

27. Eceiza, A., Caba, K.D.L., Kortaberria, G., Gabilondo, N., Marieta, C., Corcuera, M.A. Influence of Molecular Weight and Chemical Structure of Soft Segment in Reaction Kinetics of Polycarbonate Diols with 4,4'-Diphenylmethane Diisocyanate European Polymer Journal 41 (12) 2005: pp. $3051-3059$.

https://doi.org/10.1016/j.eurpolymj.2005.06.022

28. Pavliević, J., Spirkova, M., Strachota, A., Szecsenyi, K.M., Lazic, N., Budinski-Simendic, J. The Influence of Montmorillonite and Bentonite addition on Thermal Properties of Polyurethanes Based on Aliphatic Polycarbonate Diols Thermochimica Acta $509(1-2)$ 2010: pp. $73-80$. https://doi.org/10.1016/j.tca.2010.06.005

29. Liu, N., Zhao, Y., Kang, M., Wang, J., Wang, X., Feng, Y., 
Yin, N., Li, Q. The Effects of the Molecular Weight and Structure of Polycarbonatediols on the Properties of Waterborne Polyurethanes Progress in Organic Coatings 82 (5) 2015: pp. 46-56.

https://doi.org/10.1016/j.porgcoat.2015.01.015

30. Oh, S.Y., Kang, M.S., Knowles, J.C., Gong, M.S. Synthesis of Bio-based Thermoplastic Polyurethane Elastomers Containing Isosorbide and Polycarbonate Diol and Their Biocompatible Properties Journal of Biomaterials Applications 30 (3) 2015: pp. 327-337.

https://doi.org/10.1177/0885328215590054

31. Liu, J., Liu, Q., Zheng, X., Liu, R., Mu, Q., Liu, X. Synthesis of UV-Curable Polycarbonate Diols (PCDL)-based Polyurethane Acrylate for Negative Photoresist Polymer Bulletin 73 (3) 2016: pp. 647-659.

https://doi.org/10.1007/s00289-015-1511-4

32. Yang, J., Gao, Y., Li, J., Ding, M., Chen, F., Tan, H., Fu, Q. Synthesis and Microphase Separated Structures of Polydimethylsiloxane/Polycarbonate-based Polyurethanes RSC Advances 3 (22) 2013: pp. 8291-8297. https://doi.org/10.1039/c3ra40515j

33. Costa, V., Nohales, A., Félix, P., Guillem, C., Gutierrez, D. Gomez, C.M. Structure-property Relationships of Polycarbonate Diol-Based Polyurethanes as a Function of Soft Segment Content and Molar Mass Journal of Applied Polymer Science 132 (12) 2015: pp. 1-10. https://doi.org/10.1002/app.41704

34. Sun, Y., Zhao, C., Xiao, J. Reparation and Characterization of Water-borne Polyurethane Based on PCDL or (and) PCL Prepolymer AIP Conference Proceedings 1864 (1) 2017: pp. $1-5$.

https://doi.org/10.1063/1.4993021

35. Orgilés-Calpena, E., Arán-Ais, F., Torró-Palau, A.M., Orgiles-Barcelo, C. Novel Polyurethane Reactive Hot Melt Adhesives Based on Polycarbonate Polyols Derived from $\mathrm{CO}_{2}$ for The Footwear Industry International Journal of Adhesion and Adhesives 70 (7) 2016: pp. 218-224. https://doi.org/10.1016/j.ijadhadh.2016.07.009

36. Debolt, M., Kiziltas, A., Mielewski, D., Waddington, S., Nagridge, M.J. Flexible Polyurethane Foams Formulated with Polyols Derived from Waste Carbon Dioxide Journal of Applied Polymer Science 133 (45) 2016: pp. 1-11. https://doi.org/10.1002/app.44086

37. Busygin, I., Muller, T.E., Gurtler, C., Kermagoret, A., Dienes, Y., Kohler, B., Leitner, W. Method for Producing Polycarbonate Polyols by The Immortal Polymerization of Cyclic Carbonates U.S. Patent No.20140018517. https://doi.org/CA2816641 A1

38. Scharfenberg, M., Hofmann, S., Preis, J., Hilf, J., Frey, H. Rigid Hyperbranched Polycarbonate Polyols from $\mathrm{CO}_{2}$ and Cyclohexene-based Epoxides Macromolecules 50 (16) 2017: pp. $6088-6097$. https://doi.org/10.1021/acs.macromol.7b01276

39. Lim, J., Yun, S.H., Kim, M.R., Kim, I. Synthesis of Polycarbonate Polyols by Double-metal Cyanide Catalyzed Copolymerization of Epoxide with Carbon Dioxide Journal of Nanoscience and Nanotechnology 17 (10) 2017: pp. $7507-7514$.

https://doi.org/10.1166/jnn.2017.14796

40. Orgilés-Calpena, E., Arán-Ais, F., Torró-Palau, A.M., Orgiles-Barcelo, C. Novel Polyurethane Reactive Hot Melt Adhesives Based on Polycarbonate Polyols Derived from $\mathrm{CO}_{2}$ for the Footwear Industry International Journal of Adhesion and Adhesives 70 (7) 2016: pp. 218-224. https://doi.org/10.1016/j.ijadhadh.2016.07.009
41. Chapman, A.M., $\quad$ Keyworth, C., $\quad$ Kember, M.R., Lennox, A.J.J., Williams, C.K. Adding Value to Power Station Captured $\mathrm{CO}_{2}$ : Tolerant $\mathrm{Zn}$ and $\mathrm{Mg}$ Homogeneous Catalysts for Polycarbonate Polyol Production ACS Catalysis 5 (3) 2015: pp. 1581-1588. https://doi.org/10.1021/cs501798s

42. Hilf, J., Schulze, P., Seiwert, J., Frey, H. Controlled Synthesis of Multi-arm Star Polyether-polycarbonate Polyols Based on Propylene Oxide and $\mathrm{CO}_{2}$ Macromolecular Rapid Communications 35 (2) 2014: pp. 198-203. https://doi.org/10.1002/marc.201300663

43. Wu, G.P., Darensbourg, D.J. Mechanistic Insights into Water-Mediated Tandem Catalysis of Metal-coordination $\mathrm{CO}_{2}$ /Epoxide Copolymerization and Organocatalytic Ringopening Polymerization: One-pot, Two Steps, and Three Catalysis Cycles for Triblock Copolymers Synthesis Macromolecules 49 (3) 2016: pp. 807-814. https://doi.org/10.1021/acs.macromol.5b02752

44. Scharfenberg, M., Seiwert, J., Scherger, M., Preis, J., Susewind, M., Frey, H. Multiarm Polycarbonate Star Polymers with a Hyperbranched Polyether Core from $\mathrm{CO}_{2}$ and Common Epoxides Macromolecules 50 (17) 2017: pp. $6577-6585$. https://doi.org/10.1021/acs.macromol.7b01131

45. Kim, J.G., Cowman, C.D., Lapointe, A.M., Wiesner, U., Coates, G.W. Tailored Living Block Copolymerization: Multiblock Poly(Cyclohexene Carbonate)s with Sequence Control Macromolecules 44 (5) 2011: pp. 1110-1113. https://doi.org/10.1021/ma102585a

46. Wang, Y. Trivalent Titanium Salen Complex: Thermally Robust and Highly Active Catalyst for Copolymerization of $\mathrm{CO}_{2}$ and Cyclohexene Oxide ACS Catalysis $5(1)$ 2014: pp. $393-396$. https://doi.org/10.1021/cs501719v

47. Zhang, D.Y., Zhang, H.F., Hadjichristidis, N., Gnanou, Y., Feng, X.S. Lithium-assisted Copolymerization of $\mathrm{CO}_{2} /$ Cyclohexene Oxide: A Novel and Straightforward Route to Polycarbonates and Related Block Copolymers Macromolecules 49 (7) 2016: pp. 2484-2492. https://doi.org/10.1021/acs.macromol.6b00203

48. Chakraborty, D., Mandal, M., Ramkumar, V. Zr (IV) Complexes Containing Salan-type Ligands: Synthesis, Structural Characterization and Role as Catalysts towards the Polymerization of $\varepsilon$-Caprolactone, rac-Lactide, Ethylene, Homopolymerization and Copolymerization of Epoxides with $\mathrm{CO}_{2}$ RSC Advances 5 (36) 2015: pp. 28536-28553. https://doi.org/10.1039/c4ra17201a

49. Asmussen, S.V., Arenas, G.F., Vallo, C.I. Enhanced Degree of Polymerization of Methacrylate and Epoxy Resins by Plasmonic Heating of Embedded Silver Nanoparticles Progress in Organic Coatings 88 (11) 2015: pp. 220-227. https://doi.org/10.1016/j.porgcoat.2015.06.032

50. Wang, Y. Trivalent Titanium Salen Complex: Thermally Robust and Highly Active Catalyst for Copolymerization of $\mathrm{CO}_{2}$ and Cyclohexene Oxide ACS Catalysis 5 (1) 2014: pp. 393-396. https://doi.org/10.1021/cs501719v

51. Wei, J., Riffel, M.N., Diaconescu, P. L. Redox Control of Aluminum Ring-opening Polymerization: A Combined Experimental and DFT Investigation Macromolecules 50 (5) 2017: pp. $1847-1861$. https://doi.org/10.1021/acs.macromol.6b02402

52. Kernbichl, S., Reiter, M., Adams, F., Vagin, S., Rieger, B. $\mathrm{CO}_{2}$-controlled One-pot Synthesis of AB, ABA Block, and Statistical Terpolymers from $\beta$-Butyrolactone, Epoxides, and 
$\mathrm{CO}_{2}$ Journal of the American Chemical Society

$139(20)$

2017: pp. $6787-6790$.

https://doi.org/10.1021/jacs.7b01295

53. Uyar, Z., Degirmenci, M., Genli, N., Yilmaz, A. Synthesis of Well-defined Bisbenzoin End-functionalized Poly $(\varepsilon-$ Caprolactone) Macrophotoinitiator by Combination of ROP and Click Chemistry and Its Use in The Synthesis of Star Copolymers by Photoinduced Free Radical Promoted Cationic Polymerization Designed Monomers \& Polymers 20 (1) 2017: pp. $42-53$.

https://doi.org/10.1080/15685551.2016.1231041

54. Guerin, W., Diallo, A.K., Kirilov, E., Helou, M., Slawinski, M., Brusson, J.M. Carpentier, J.F., Guillaume, S.M. Enantiopure Isotactic Pchc Synthesized by Ring-opening Polymerization of Cyclohexene Carbonate Macromolecules 47 (13) 2014: pp. 4230-4235. https://doi.org/10.1021/ma5009397

55. Diallo, A.K., Guerin, W., Slawinski, M., Brusson, J.M., Carpentier, J.F., Guillaume, S.M. Block and Random Copolymers of 1,2-Cyclohexyl Cyclocarbonate and 1-Lactide or Trimethylene Carbonate Synthesized by Ring-Opening Polymerization Macromolecules $48(10)$ 2015: pp. $3247-3256$.

https://doi.org/10.1021/acs.macromol.5b00548

56. Scharfenberg, M., Hofmann, S., Preis, J., Hilf, J., Frey, H. Rigid Hyperbranched Polycarbonate Polyols from $\mathrm{CO}_{2}$ and Cyclohexene-based Epoxides Macromolecules 50 (16) 2017: pp: $6088-6097$.

https://doi.org/10.1021/acs.macromol.7b01276

57. Liu, Q.Y., Zou, Y.N., Bei, Y.L., Qi, G.B., Meng, Y.Z. Mechanic Properties and Thermal Degradation Kinetics of Terpolymer Poly(Propylene Cyclohexene Carbonate)s Materials Letters $62(17-18)$ 2008: pp. 3294-3296. https://doi.org/10.1016/j.matlet.2008.02.045

58. Tokiwa, Y., Calabia, B.P. Biodegrability and Biodegradation of Polyesters Journal of Polymer and the Environment 15 (4) 2007: pp. $259-267$. https://doi.org/10.1007/s10924-007-0066-3

59. Tokiwa, Y., Jarerat, A. Microbial Biodegradation of Aliphatic Polyesters Macromolecular Symposia 201 (1) 2003: pp. $283-290$. https://doi.org/10.1002/masy.200351131

60. Mochizuki, M. Properties and Application of Aliphatic Polyester Products Cheminform 34 (7) 2003: pp. 25-30. https://doi.org/10.1002/chin.200307229

61. Okada, M. Chemical Syntheses of Biodegradable Polymers Progress in Polymer Science 27 (1) 2002: pp. 87-133. https://doi.org/10.1016/S0079-6700(01)00039-9

62. Meabe, L., Sardon, H., Mecerreyes, D. Hydrolytically Degradable Poly(Ethylene Glycol) Based Polycarbonates by Organocatalyzed Condensation European Polymer Journal 95 (10) 2017: pp. $737-745$.

https://doi.org/10.1016/j.eurpolymj.2017.06.046

63. Darensbourg, D.J. Making Plastics from Carbon Dioxide: Salen Metal Complexes as Catalysts for The Production of Polycarbonates from Epoxides and $\mathrm{CO}_{2}$ Chemical Reviews 107 (6) 2007: pp. 2388-2410. https://doi.org/10.1021/cr068363q

64. Mullen, B.D., Tang, C.N., Storey, R.F. New Aliphatic Poly (Ester-Carbonates) Based on 5-Methyl-5-Allyloxycarbonyl-1, 3-Dioxan-2-One Journal of Polymer Science Part A Polymer Chemistry 41 (13) 2003: pp. 1978-1991. https://doi.org/10.1002/pola.10724

65. Shibasaki, Y., Sanada, H., Yokoi, M. Sanda, F., Endo, T. Activated Monomer Cationic Polymerization of Lactones and the Application to Well-defined Block Copolymer Synthesis with Seven-Membered Cyclic Carbonate Macromolecules 33 (12) 2000: pp. 4316-4320.

https://doi.org/10.1021/ma992138b

66. Weilandt, K.D., Keul, H., Hartwig, H. Synthesis and RingOpening Polymerization of 2-Acetoxymethyl-2Alkyltrimethylene Carbonates and of 2-Methoxycarbonyl-2Methyltrimethylene Carbonate; a Comparison with the Polymerization of 2, 2-Dimethyltrimethylene Carbonate Macromolecular Chemistry \& Physics 197 (11) 1996: pp. $3851-3868$.

https://doi.org/10.1002/macp.1996.021971128

67. Wurm, B., Keul, H., Hocker, H. Dibutylmagnesium-an Initiator for The Ring-opening Polymerization of 2, 2Dimethyltrimethylene Carbonate and $\varepsilon$-Caprolactone Makromolekulare Chemie Rapid Communications 13 (1) 1992: pp. 9-14.

https://doi.org/10.1002/marc.1992.030130102

68. Matsuo, J., Sanda, F., Endo, T. Substituent Effect on Cationic Ring-opening Polymerization Behavior of Sevenmembered Cyclic Carbonates Macromolecular Chemistry \& Physics 201 (5) 2000: pp. 585-596.

https://doi.org/10.1002/(SICI)15213935(20000301)201:53.0.CO;2-N

69. Zafer, U., Mustafa, D., Ayse, Y., Nasrettin, G. Synthesis of Well-defined Bisbenzoin End-functionalized Poly ( $\varepsilon-$ Caprolactone) Macrophotoinitiator by Combination of ROP and Click Chemistry and Its Use in The Synthesis of Star Copolymers by Photoinduced Free Radical Promoted Cationic Polymerization Designed Monomers and Polymers 20 (1) 2017: pp. $42-53$

https://doi.org/10.1002/10.1080/15685551.2016.1231041

70. Mecerreyes, D., Dahan, D., Lecomte, P., Dubois, P., Demonceau, A., Noels, A.F. Ring-opening Metathesis Polymerization of New $\alpha$-Norbornenyl Poly ( $\varepsilon$-Caprolactone) Macromonomers Journal of Polymer Science Part A Polymer Chemistry 37 (14) 1999: pp. 2447-2455. https://doi.org/10.1002/(SICI)10990518(19990715)37:143.0.CO;2-9

71. Terao, K., Miyake, J., Watanabe, J., Ikeda, Y. Regulation of Protein Loading on Poly (Trimethylene Carbonate), Poly(1Lactic Acid), and Their Copolymer: Effect of Surface Enrichment by Polymer Crystallinity Materials Science \& Engineering: C (Materials for Biological Applications) 32 (4) 2012: pp. $988-993$. https://doi.org/10.1016/j.msec.2012.02.026

72. Gao, B., Li, X., Duan, R., Duan, Q., Li, Y.H., Pang, X., Zhuang, H.J., Chen, X.S. Hemi-Salen Aluminum Catalysts Bearing N, N, O-Tridentate Type Binaphthyl-schiff-base Ligands for the Living Ring-Opening Polymerisation of Lactide RSC Advances 5 (37) 2015: pp. 29412-29419. https://doi.org/10.1039/C5RA00956A

73. Zhu, K.J., Hendren, R.W., Jensen, K., Pitt, C.G. Synthesis, Properties, and Biodegradation of Poly(1,3Trimethylene Carbonate) Macromolecules 24 (8) 1991: pp. $1736-1740$. https://doi.org/10.1021/ma00008a008

74. Gross, R.A., Kumar, A., Kalra, B. ChemInform Abstract: Polymer Synthesis by in Vitro Enzyme Catalysis Cheminform 32 (38) 2010: pp. 2097-2124. https://doi.org/10.1002/chin.200138292

75. Zhang, X., Jones, G.O., Hedrick, J.L., Waymouth, R.M. Fast and Selective Ring-opening Polymerizations by Alkoxides and Thioureas Nature Chemistry 8 (11) 2016: pp. $1047-1053$. https://doi.org/10.1038/nchem.2574 
76. Huang, M., Ma, H. Magnesium and Zinc Complexes Supported by N, N, O Tridentate Ligands: Synthesis and Catalysis in the Ring-opening Polymerization of rac-Lactide and $\alpha$-Methyltrimethylene Carbonate European Journal of Inorganic Chemistry 2016 (23) 2016: pp. 3791-3803. https://doi.org/10.1002/ejic.201600441

77. Dagorne, S., Normand, M., Kirillov, E., Carpentier, J.F. Gallium and Indium Complexes for Ring-opening Dolymerization of Cyclic Ethers, Esters and Carbonates Coordination Chemistry Reviews $257(11-12)$ 2013: pp. $1869-1886$. http://dx.doi.org/10.1016/j.ccr.2013.02.012

78. Ling, J., Shen, J., Hogenesch, T.E. A Density Functional Theory Study of the Mechanisms of Scandium-alkoxide Initiated Coordination-insertion Ring-opening Polymerization of Cyclic Esters Polymer 50 (15) 2009; pp. $3575-3581$. http://dx.doi.org/10.1016/j.polymer.2009.06.006

79. Diallo, A.K., Guerin, W., Slawinski, M., Brusson, J.M., Guillaume, S.M. Block and Random Copolymers of 1, 2Cyclohexyl Cyclocarbonate and L-Lactide or Trimethylene Carbonate Synthesized by Ring-opening Polymerization Macromolecules 48 (10) 2015: pp. 3247-3256. http://dx.doi.org/10.1021/acs.macromol.5b00548

80. Zhu, K.J., Hendren, R.W., Jensen, K., Pitt, C.G. Synthesis, Properties, and Biodegradation of Poly(1,3Trimethylene Carbonate) Macromolecules 24 (8) 1991: pp. $1736-1740$. http://dx.doi.org/10.1021/ma00008a008

81. Gross, R.A., Kumar, A., Kalra, B. ChemInform Abstract: Polymer Synthesis by in Vitro Enzyme Catalysis Cheminform 32 (38) 2010: pp. 2097-2124. https://doi.org/10.1002/chin.200138292

82. Gross, R.A., Kalra, B., Kumar, A. Polyester and Polycarbonate Synthesis by in Vitro Enzyme Catalysis Applied Microbiology \& Biotechnology 55 (6) 2001: pp. $655-660$. https://doi.org/10.1007/s002530100617

83. Chan, J.M.W., Zhang, X., Brennan, M.K., Sardon, H., Engler, A.C., Fox, C.H., Frank, C.W., Waymouth, R.W., Hedrick, J.L. Organocatalytic Ring-opening Polymerization of Trimethylene Carbonate to Yield a Biodegradable Polycarbonate Journal of Chemical Education 92 (4) 2015: pp. $708-713$.

http://dx.doi.org/10.1021/ed500595k

84. Albertsson, A.C., Srivastava, R.K. Recent Developments in Enzyme-catalyzed Ring-opening Polymerization Advanced Drug Delivery Reviews 60 (9) 2008: pp. 1077-1093. http://dx.doi.org/10.1016/j.addr.2008.02.007

85. Zhao, H. Enzymatic Ring-Opening Polymerization (ROP) of Polylactones: Roles of Non-Aqueous Solvents Journal of Chemical Technology \& Biotechnology 93 (1) 2018: pp. 9-19. https://doi.org/10.1002/jctb.5444

86. Champagne, E., Strandman, S., Zhu, X.X. Recent Developments and Optimization of Lipase-Catalyzed Lactone Formation and Ring-Opening Polymerization Macromolecular Rapid Communications 37 (24) 2016: pp. $1-9$. https://doi.org/10.1002/marc.201600494

87. Dai, S., Xue, L., Li, Z. Enzymatic Ring-Opening Polymerization of Trimethylene Carbonate with Macrodiol: Synthesis of Block Poly (Ester-co-Carbonate) for Biomaterial Preparation Acs Catalysis 1 (10) 2011: pp. 1421-1429. http://dx.doi.org/10.1021/cs200407n
88. Sobczak, M. Enzyme-Catalyzed Ring-opening Polymerization of Cyclic Esters in the Presence of Poly (Ethylene Glycol) Journal of Applied Polymer Science 125 (5) 2012: pp. 3602-3604.

http://dx.doi.org/10.1002/app.36396

89. Feng, J., He, F., Zhuo, R. Polymerization of Trimethylene Carbonate with High Molecular Weight Catalyzed by Immobilized Lipase on Silica Microparticles Macromolecules 35 (19) 2002: pp. 7175-7177. http://dx.doi.org/10.1021/ma0255579

90. Kobayashi, S., Uyama, H., Namekawa, S. In Vitro Biosynthesis of Polyesters with Isolated Enzymes in Aqueous Systems and Organic Solvents Polymer Degradation \& Stability $59(1-3)$ 1998: pp. 195-201. http://dx.doi.org/10.1016/S0141-3910 (97)00178-X

91. Nobes, G.A.R., Kazlauskas, R.J., Marchessault, R.H. Lipase-Catalyzed Ring-Opening Polymerization of Lactones: A Novel Route to Poly (Hydroxyalkanoate)s Macromolecules 29 (14) 1996: pp. 4829-4833. http://dx.doi.org/10.1021/ma951774g

92. Normand, M., Kirillov, E., Roisnel, T., Carpentier, J.F. Indium Complexes of Fluorinated Dialkoxy-diimino Salenlike Ligands for Ring-Opening Polymerization of racLactide: How Does Indium Compare to Aluminum? Organometallics 31 (4) 2012: pp. 1448-1457. http://dx.doi.org/10.1021/om200906e

93. Dubois, P., Coulembier, O., Raquez, J.M. Handbook of Ring-opening Polymerization. Wiley-VCH, Germany, 2009: pp. 53-62. http://dx.doi.org/10.1002/9783527628407

94. Hyun, H., Kim, M.S., Khang, G., Lee, H.B. Ring-opening polymerization of Trimethylene Carbonate by Poly(Ethylene Glycol) in The Presence of $\mathrm{HCl} \cdot \mathrm{Et}_{2} \mathrm{O}$ as a Monomer Activator Journal of Polymer Science Part A Polymer Chemistry 44 (13) 2010: pp. 4235 - 4241. http://dx.doi.org/10.1002/pola.21504

95. Kim, J., Ju, K.H., Yeon, K.D., Lee, B., Chun, H.J., Kim, J.H., Kim, M.S. Ring-opening Polymerization of Cyclic Ester Monomers by Poly(propylene glycol) in the Presence of Monomer Activator and Examination of Triblock Copolymer Solution Properties Current Nanoscience 7 (6) 2011: pp. $955-960$. http://dx.doi.org/10.2174/157341311798220790

96. Matsuo, J., Nakano, S., Sanda, F., Endo, T. Ring-Opening Polymerization of Cyclic Carbonates by Alcohol-acid Catalyst Journal of Polymer Science Part A Polymer Chemistry 36 (14) 1998: pp. 2463-2471. http://dx.doi.org/10.1002/(SICI)10990518(199810)36:14<2463::AID-POLA4>3.0.CO;2-U

97. Muller, E., Wilhelm, K., Joszef, I., Wilhelm, T. Hydrolysis Resistant Elastomeric Poly (Carbonate Urethanes) U.S. Patent No.3509233.

98. Schappacher, M., Fabre, T., Mingotaud, A.F., Soum, A. Study of a (Trimethylenecarbonate-co-Epsilon-Caprolactone) Polymer Part 1: Preparation of a New Nerve Guide Through Controlled Random Copolymerization Using Rare Earth Catalysts Biomaterials 22 (21) 2001: pp. 2849-2855. http://dx.doi.org/10.1016/S0142-9612 (01)00029-1

99. Pêgo, A.P., Poot, A.A., Grijpma, D.W., Feijen, J. Copolymers of Trimethylene Carbonate and $\varepsilon$-Caprolactone for Porous Nerve Guides: Synthesis and Properties Journal of Biomaterials Science, Polymer Edition $12(1)$ 2001: pp. 35-53.

http://dx.doi.org/10.1163/156856201744434 
100. Khan, I., Smith, N., Jones, E., Finch, D.S., Cameron, R.E. Analysis and Evaluation of a Biomedical Polycarbonate Urethane Tested in an in Vitro Study and an Ovine Arthroplasty Model. Part I: Materials Selection and Evaluation Biomaterials 26 (6) 2005: pp. 621-631. http://dx.doi.org/10.1016/j.biomaterials.2004.02.065
101. Steblyanko, A., Choi, W., Sanda, F., Endo, T. Addition of Five-membered Cyclic Carbonate with Amine and Its Application to Polymer Synthesis Journal of Polymer Science Part A Polymer Chemistry 38 (13) 2000: pp. 2375 - 2378. http://dx.doi.org/10.1002/1099-0518 